\title{
PERSEPSI SISWA TERHADAP KETERAMPILAN MENGAJAR GURU MENGGUNAKAN MEDIA VISUAL
}

\author{
Ria Fajrin Rizqy Ana \\ Universitas Bhinneka PGRI Tulungagung \\ Email: ria.fajin@stkippgritulungagung.ac.id
}

\begin{abstract}
Abstrak
Tujuan dari penelitian ini adalah untuk mendeskripsikan: (1) keterampilan mengajar guru dengan menggunakan media visual gambar, (2) kendala yang dialami guru dalam menerapkan keterampilan mengajarnya dengan menggunakan media visual gambar, dan (3) persepsi siswa terhadap keterampilan mengajar guru dengan menggunakan media visual gambar. Jenis penelitian ini adalah penelitian kualitatif, subjek penelitian adalah siswa kelas III yang berjumlah 20 siswa. Instrumen penelitian menggunakan pedoman observasi, pedoman wawancara dan lembar angket. Analisis data menggunakan reduksi data, penyajian data dan penarikan kesimpulan .

Hasil penelitian menunjukkan guru sudah melaksanakan delapan keterampilan mengajarnya dengan menggunakan media visual gambar. Kendala yang dialami guru yaitu guru kekurangan waktu dalam proses persiapan media. Persepsi siswa terhadap pembelajaran yang dilakukan guru yaitu siswa terlihat antusias dalam mengikuti pembelajaran di kelas. Siswa lebih bersemangat mengikuti pembelajaran, siswa lebih mudah memahami materi pelajaran dan siswa terlihat rajin belajar karena pembelajaran menjadi menyenangkan. Hendaknya guru selalu menerapkan keterampilan mengajarnya dengan menggunakan media visual gambar dalam kegiatan pembelajaran di kelas.
\end{abstract}

Kata Kunci : keterampilan mengajar, media visual, persepsi guru

\section{Abstract}

The purpose of this study is to describe: (1) teacher teaching skills using visual media images, (2) obstacles experienced by teachers in applying their teaching skills using visual media images, and (3) students' perceptions of teacher teaching skills using media visual image. The type of this research is qualitative research, the research subjects are grade III students, amounting to 20 students. The research instrument used observation guidelines, interview guidelines and questionnaire sheets. Data analysis uses data reduction, data presentation and conclusion drawing.

The results showed the teacher had implemented eight teaching skills using visual media images. The obstacle experienced by the teacher is that the teacher lacks time in the media preparation process. Students' perceptions of the learning that teachers do that students look enthusiastic in participating in learning in class. Students are 
more eager to follow the learning, students more easily understand the subject matter and students look diligent in learning because learning becomes fun. Teachers should always apply their teaching skills by using visual media images in classroom learning activities.

Keywords: teaching skills, visual media, teacher perception

\section{Pendahuluan}

Pada era globalisasi, institusi pendidikan mengemban tugas penting untuk menyiapkan Sumber Daya Manusia (SDM) Indonesia yang berkualitas dimasa depan. Guru memegang kunci utama bagi peningkatan mutu SDM masa depan terutama dibidang pendidikan. Guru adalah faktor penting dalam penyelenggaraan kegiatan pembelajaran di sekolah, sehingga guru harus professional dalam menyelenggarakan proses pembelajaran. Kualitas pembelajaran berdasarkan dari kemampuan, kreativitas, dan motivasi guru dalam mengembangkan kegiatan pembelajarannya. Standar kompetensi harus dikuasai dan ditingkatkan, tidak hanya dari segi kesejahteraannya (Sagala, 2011).

Guru sebagai tenaga profesional harus memiliki kompetensi keguruan. Kompetensi keguruan itu tampak pada kemampuan guru dalam memberikan keterampilan mengajar pada proses pembelajaran sehingga pelajaran yang diberikan guru dapat diterima oleh siswa. Keterampilan mengajar guru merupakan suatu hal yang penting dalam proses pembelajaran karena salah satu cara yang dapat dilakukan guru agar proses pembelajaran di kelas dapat menumbuhkan semangat belajar siswa adalah dengan menggunakan keterampilan mengajar. Keterampilan dasar mengajar sebagai salah satu syarat mutlak untuk mencapai keefektifan pembelajaran (Suparman, 2010).

Mengajar merupakan proses yang mengandung serangkaian tindakan guru dan siswa atas dasar hubungan timbal balik yang berlangsung dalam situasi edukatif untuk mencapai tujuan tertentu (Septiani, Yohanes, \& Izhar, 2014). Interaksi inilah yang menjadi syarat utama dalam berlangsungnya proses belajar mengajar. Tercapai atau tidaknya suatu proses pembelajaran dapat dilihat dari prestasi yang dicapai oleh siswa. Sedangkan prestasi yang dicapai oleh siswa berhubungan dengan hasil belajar. Salah satu usaha untuk meningkatkan hasil belajar adalah melalui peran guru. Guru harus dapat menerapkan cara mengajar yang beragam dan tepat dalam proses belajar 
mengajar, sehingga materi pelajaran akan lebih dapat diterima siswa dengan optimal.

Kemampuan yang dimiliki seorang guru juga berpengaruh pada siswanya, jika pengajaran yang dilakukan guru bervariasi maka siswa juga dengan mudah dapat memahami materi pelajaran yang diajarkan. Guru harus memiliki keterampilan dalam mengajar agar memberikan suasana yang berbeda sehingga siswa tidak bosan dalam mengikuti kegiatan pembelajaran. Guru juga harus menciptakan keadaan kelas yang menumbuhkan semangat siswa untuk belajar. Hal penting yang harus diperhatikan adalah pemilihan kegiatan yang menarik bagi siswa. Seorang guru juga harus dapat mengembangkan keterampilan mengajar dengan baik, sehingga minat belajar siswanya tinggi.

Pada proses belajar mengajar kemampuan siswa dalam menerima atau menangkap materi pelajaran berbeda-beda. Semuanya dipengaruhi tingkat kepandaian yang dimiliki setiap siswa dan juga persepsi yang dimiliki siswa terhadap pengajar. Adanya perbedaan persepsi yang dimiliki oleh siswa akan berpengaruh kepada perbedaan motivasi belajar pada masing-masing siswa di kelas. Agar motivasi belajar dan persepsi setiap siswa sama dalam kelas maka guru sebagai pengajar diharapkan mampu menciptakan suasana belajar mengajar menjadi menarik dan menyenangkan.

Peserta didiklah yang paling sering berhubungan dengan guru, sehingga segala sikap, perilaku, kinerja, cara mengajar, kedisiplinan, siswalah yang paling mengetahui. Selain itu, siswa juga yang dapat merasakan dampak dari pengajaran guru yang terampil dan bervariasi. Baiknya cara mengajar guru akan membuat siswa cepat menguasai kompetensi yang akan dicapai. Sehingga persepsi siswa merupakan hal penting yang harus diketahui guna melihat bagaimana keterampilan mengajar guru dilapangan secara kenyataan. Pemahaman siswa juga harus dituntut sama dalam satu kelas pada saat proses pembelajaran, jika siswa memiliki pemahaman yang berbeda-beda antara siswa yang satu dengan yang lainnya maka dapat mempengaruhi persepsi siswa pada saat menerima pelajaran bahkan pada saat ujian. Persepsi siswa yang salah pada saat menerima pelajaran dapat menimbulkan pemikiran yang salah juga hingga jenjang sekolah selanjutnya.

Penggunaan media pembelajaran untuk menunjang kegiatan belajar 
mengajar sangatlah penting dalam dunia pendidikan dan bukan hal yang baru lagi. Guru dituntut untuk lebih kreatif dalam kegiatan belajar mengajar agar ilmu yang diberikan dapat diterima oleh siswa. Namun keadaan yang terjadi saat ini media pembelajaran mulai tidak diperhatikan lagi oleh para guru, guru hanya menggunakan metode ceramah saja dan mengabaikan media yang mereka gunakan dengan alasan materi pelajaran yang berat, serta penggunaan media pembelajaran yang sangat minim sekali dengan alasan biaya pengadaan media pembelajaran mahal.

Pada saat proses belajar mengajar kehadiran media mempunyai arti yang cukup penting, karena dalam kegiatan tersebut ketidakjelasan bahan yang disampaikan dapat dibantu dengan menghadirkan media sebagai perantara.

Diantara media pembelajaran, media visual adalah media yang paling umum dipakai. Hal ini dikarenakan siswa lebih menyukai gambar daripada tulisan, apalagi jika gambarnya dibuat dan disajikan sesuai dengan persyaratan gambar yang baik, tentunya akan menambah semangat siswa dalam mengikuti proses pembelajaran. Media visual tidak memerlukan biaya yang mahal dalam pengadaannya serta media gambar sangat mudah didapat, sehingga guru tidak akan mengalami kesulitan dalam proses persiapan media pembelajaran sebelum kegiatan pembelajaran di kelas.

Berdasarkan hasil observasi yang dilakukan di SDN Kendalrejo 02, menunjukkan bahwa siswa kurang antusias mengikuti pembelajaran yang diterapkan oleh guru. Guru hanya membacakan teks, siswa duduk mendengarkan ceramah dari guru. Terlihat banyak siswa yang bermain sendiri, berbicara dengan temannya, bahkan ada juga yang terlihat tertidur ketika pembelajaran berlangsung. Hal ini diakibatkan dari keterampilan yang digunakan oleh guru masih kurang. Guru menerapkan keterampilan mengajar bertanya, dan menjelaskan. Selain itu, guru juga tidak menggunakan media pembelajaran dalam menyampaikan materi. Padahal penggunaan media pembelajaran sangat penting untuk diterapkan.

Dari hasil wawancara dengan kepala sekolah, ternyata kepala sekolah menuntut penggunaan media pada pembelajaran karena tujuan dari penggunaan tersebut agar siswa antusias dalam mengikuti kegiatan pembelajaran dan siswa menjadi aktif. Selain dari penggunaan media visual gambar, guru juga dituntut untuk lebih 
kreatif dalam kegiatan mengajarnya. Pembelajaran yang menggunakan media pembelajaran dapat menciptakan suasana yang lebih menyenangkan dan guru kelas lebih mengutamakan pemahaman siswa, persepsi siswa, dan kemampuan siswa. Berdasarkan permasalahan di atas tujuan dari penelitian ini yaitu (1) Untuk mendeskripsikan keterampilan mengajar guru dengan menggunakan media visual, (2) mengetahui kendala yang dialami guru dalam menerapkan keterampilan mengajarnya dengan menggunakan media visual, dan mendeskripsikan persepsi siswa terhadap keterampilan mengajar guru dengan mengguanakan media visual.

\section{Metode penelitian}

Jenis penelitian yang digunakan yaitu kualitatif dengan pendekatan deskriptif. Penelitian deskriptif yaitu penelitian yang berusaha untuk menuturkan pemecahan masalah berdasarkan data-data. Penelitian deskriptif kualitatif pada penelitian ini dimaksudkan untuk memperoleh informasi mengenai persepsi siswa terhadap keterampilan mengajar guru dengan menggunakan media visual gambar di kelas III SDN Kendalrejo 02 secara mendalam dan komprehensif.
Selain itu, dengan pendekatan kualitatif diharapkan dapat mengungkapkan situasi dan permasalahan yang dihadapi guru dalam menerapkan keterampilan mengajarnya menggunakan media visual gambar.

Prosedur penelitian yang dilaksanakan dalam penelitian ini meliputi tiga tahap yaitu tahap pra lapangan, tahap pekerjaan lapangan, dan tahap analisis data digambarkan dengan alur sebagai berikut:

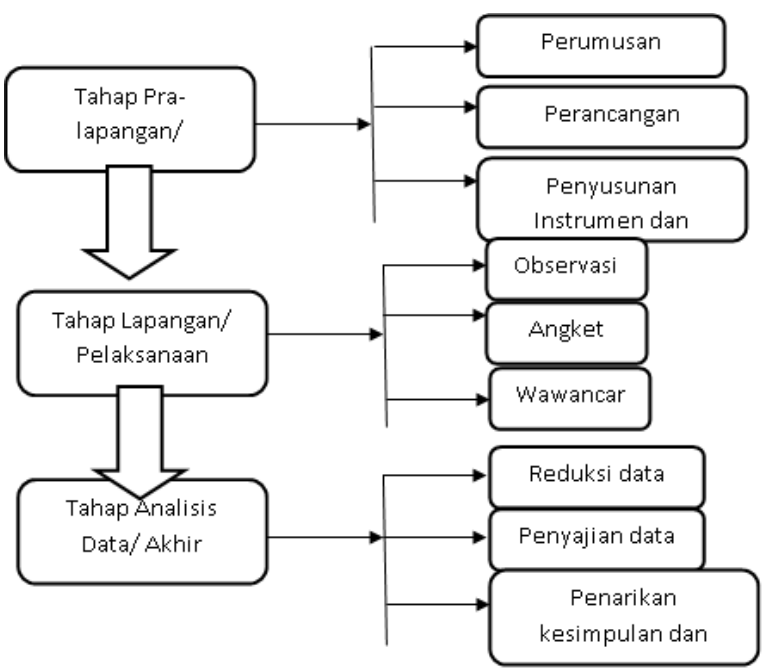

Instrumen dalam penelitian ini ada dua jenis yaitu instrumen utama dan instrumen pendukung. Instrumen utama dalam penelitian ini adalah peneliti sendiri, karena peneliti bertindak sebagai instrumen sekaligus pengumpul data yang disebut dengan peneliti sebagai instrumen kunci. Instrumen pendukung dalam penelitian ini adalah pedoman observasi, pedoman wawancara dan lembar angket. Pedoman observasi 
digunakan untuk mengetahui kegiatan guru dalam pembelajaran di kelas dan untuk mengetahui kegiatan siswa pada saat pembelajaran di kelas. Pedoman wawancara digunakan untuk mengumpulkan informasi yang masih belum di dapat dari hasil observasi, sedangkan lembar angket digunakan untuk mengetahui persepsi siswa terhadap keterampilan mengajar guru dengan menggunakan media visual gambar.

Analisis data adalah suatu proses dan menyusun secara sistematis dari hasil pengumpulan data dengan cara mengorganisasikan, menjabarkan, melakukan sintesis, memilih mana yang penting dan yang akan dipelajari, serta membuat kesimpulan sehingga mudah dipahami oleh diri sendiri maupun orang lain (Sugiyono, 2010). Secara umum Miles dan Huberman dalam Sugiyono (2010) membagi analisis data menjadi 3 tahapan, yaitu: (1) Reduksi Data (Data Reduction), merupakan proses berpikir sensitif yang memerlukan kecerdasan, keluasan dan kedalaman wawasan yang tinggi. Mereduksi data berarti merangkum, memilih hal-hal yang pokok, memfokuskan pada hal-hal yang penting, dicari tema dan polanya dan membuang yang tidak perlu; (2) Penyajian data (Data Display), Dalam penelitian kualitatif, penyajian data dilakukan dalam bentuk uraian singkat, bagan, grafik, dan sejenisnya. Dengan menyajikan data, maka akan memudahkan untuk memahami apa yang terjadi, merencanakan kerja selanjutnya berdasarkan apa yang telah dipahami. Dalam penelitian ini, data disajikan dalam bentuk teks naratif atau cerita, dan transkrip wawancara; (3) Penarikan kesimpulan dan Verifikasi adalah proses pengambilan intisari dari keseluruhan paparan atau penyajian data yang telah dideskripsikan, diformulakan dalam bentuk kalimat yang singkat dan dapat sebagai jawaban terhadap tujuan penelitian yang telah ditentukan. Kesimpulan dalam penelitian ini berupa gambaran mengenai keterampilan mengajar guru dengan menggunakan media visual gambar dan kendala yang dihadapi guru, serta persepsi siswa mengenai keterampilan mengajar guru dengan menggunakan media visual gambar. Data diperoleh dari hasil penelitian yang telah dilakukan.

\section{Hasil dan Pembahasan}

Hasil observasi yang dilakukan pada guru ketika kegiatan mengajar di dalam kelas diperoleh hasil sebagai berikut : 
Tabel 1. Hasil Observasi Kegiatan Guru Ketika Mengajar

\begin{tabular}{lll}
\hline No. & \multicolumn{1}{c}{ Kegiatan } & \multicolumn{1}{c}{ Hasil Pengamatan } \\
\hline $1 . \quad$ Kegiatan Pendahuluan & (Motivasi) \\
& Guru menanyakan apa yang dirasakan jika listrik \\
& di rumah mati dalam 1 hari. \\
& (Pengetahuan Prasarat) \\
& Guru mengajukan pertanyaan bagaimana cara \\
& menghemat energi di rumah dan di sekolah. \\
& Siswa diminta tidak membuka buku catatan pada \\
& saat guru memberikan soal secara lisan yang \\
& dikaitkan dengan kegiatan di rumah dan di \\
& sekolah. Pertanyaan yang guru berikan yaitu \\
& pertanyaan yang mengarah dan menuntun.
\end{tabular}

2. Kegiatan Inti

a) Guru menjelaskan mengenai materi pelajaran cara menghemat energi disertai contoh-contoh gambar yang dikaitkan dengan kehidupan sehari-hari.

b) Guru menjelaskan materi pelajaran dengan runtut.

c) Guru membagi siswa secara berkelompok.

d) Guru memberikan tugas secara kelompok melalui gambar yang sudah diberikan,siswa diminta untuk mendiskusikan tugas yang diberikan bersama kelompoknya.

e) Guru meminta siswa untuk mendata berbagai cara menghemat energi di rumah dan di sekolah.

f) Guru meminta siswa mendemonstrasikan cara menghemat energi melalui praktik.

g) Guru memberikan penguatan kepada siswa melalui pujian.

h) Guru memeriksa kegiatan siswa apakah sudah dilakukan dengan benar. Jika masih ada siswa yang belum dapat melakukan kegiatan dengan bear, guru membimbing siswa dan memberikan petunjuk.

i) Guru mengkondisikan keadaan ruang kelas agar tetap tenang dan kondusif, siswa juga tidak ada yang gaduh dan tetap fokus pada pelajaran dan penjelasan guru.

j) Setelah kegiatan diskusi selesai guru menjelaskan materi pelajaran yang sudah dipelajari siswa pada saat diskusi. 


\begin{tabular}{ll}
\hline & k) Guru mengadakan variasi permainan yang \\
& berhubungan dengan materi pelajaran, \\
& contohnya seperti permainan ular tangga dan \\
& talking stick. \\
\hline 3. Kegiatan Penutup & a) Guru memberi penghargaan pada kelompok \\
dengan kinerja baik. & \\
b) Guru membimbing siswa merangkum \\
pelajaran. \\
c) Guru mengadakan uji kompetensi lisan. \\
d) Guru memberikan PR kepada siswa. \\
e) Guru menutup pelajaran.
\end{tabular}

Berdasarkan tabel di atas, dapat disimpulkan bahwa guru sudah cukuo bagus dalam memberikan materi pembelajaran berbantuan media visual. Media yang digunakan guru yaitu gambar sumber energi yang berkaitan dengan kehidupan sehari-hari. Media gambar digunakan oleh guru dengan tujuan mempermudah siswa dalam memahami materi yang disampaikan. Siswa juga terlihat sangat tertarik dengan pembelajaran yang diterapkan guru. Selain itu, guru juga menggunakan variasi pembelajaran seperti permainan agar siswa tidak merasa bosan ketika mengikuti pembelajaran.

\section{Peneliti juga mengobservasi} kegiatan siswa ketika mengikuti pembelajaran yang dilakukan oleh guru. Hasil observasi yang diperoleh yaitu siswa memiliki keberanian untuk bertanya mengenai materi dan antusias memberikan pendapat dan bahkan siswa juga sering menanyakan soal-soal yang belum dipahami kepada guru dengan mengangkat tangan. Siswa juga tidak segan berjalan menuju meja guru untuk menanyakan mengenai tugas yang kurang dipahami.

Guru dan siswa memiliki hubungan yang terlihat akrab dan baik karena guru menunjukkan Bahasa tubuh yang menyayangi siswa sehingga siswa dapat dengan berani menyampaikan pertanyaan mengenai materi pelajaran. Sikap siswa dengan sesama teman terlihat saling berdiskusi mengenai materi dan soal yang diberikan guru. Selain melakukan observasi, peneliti juga melakukan wawancara untuk memperkuat hasil penelitian.

\section{Wawancara} dilakukan menggunakan teknik wawancara semiterstruktur. Berikut adalah hasil kutipan langsung wawancara yang telah peneliti lakukan dengan guru kelas III. Kutipan tersebut merupakan jawaban dari pertanyaan bagaimana proses pembelajaran dilihat dari aktivitas belajar 
siswa. Kutipan tersebut merupakan jawaban dari guru, sementara daftar pertanyaan dan seluruh jawaban bisa dilihat pada lampiran.

"kebanyakan siswa
memperhatikan guru, akan
tetapi jika tidak diselingi
dengan game, siswa akan
tidak fokus bahkan tidak
memperhatikan guru, agar
siswa tetap fokus maka
diselingi dengan game-game
atau kuis yang membuat
siswa semangat belajar lagi."
Tujuan pembelajaran dapat tercapai dengan mudah karena pembelajarannya tidak monoton bahkan siswa menjadi mudah paham materi pelajaran. Hambatan atau kesulitan yang guru temui pada saat pembelajaran dengan menerapkan keterampilan mengajar guru dengan menggunakan media visual gambar yaitu dalam proses persiapan media guru masih kekurangan waktu untuk persiapannya.

"Hambatannya yaitu dalam
proses persiapan media
karena gambar-gambar
harus mencari dulu dan
harus mencetaknya. Gambar
juga tidak bisa dicetak besar,
rata-rata ukurannya hanya
sebesar kertas, dengan
begitu harus dicetak dengan
jumlah yang banyak
disesuaikan kebutuhan agar
dapat dibagikan kepada
siswa."
Hambatan dalam penerapan
keterampilan mengajar guru dengan menggunakan media visual gambar selalu terjadi pada saat kegiatan belajar mengajar. Guru harus mampu mencari solusi yang tepat untuk mengatasi hambatan yang terjadi. Dengan begitu pembelajaran di dalam kelas akan berjalan dengan lancar.

"Untuk mengatasi hambatan
yang terjadi, saya
mengadakan selingan dalam
kegiatan belajar mengajar
seperti selingan permainan
di sela-sela materi pelajaran.
Meskipun permainan
selingan namun permainan
itu tidak lepas dari materi
pelajaran yang sedang
berlangsung, semua
dihubungkan dengan materi
pelajaran."

Wawacara juga dilakukan dengan 2 orang siswa, 1 siswa mewakili siswa aktif di dalam kelas dan 1 siswa mewakili siswa pendiam di dalam kelas. Hasil wawancara dengan siswa yaitu mengenai pendapat siswa terhadap kegiatan pembelajaran yang dilakukan guru di kelas dan mannfaat yang dirasakan setelah mengikuti pembelajaran di kelas. Menurut pendapat siswa 1 yang mewakili siswa aktif.

"Saya menjadi senang
mengikuti pembelajaran,
pembelajaran menjadi
menyenangkan, karena guru
mengadakan permainan
yang menyenangkan dan
pembelajaran menjadi tidak

"Saya menjadi senang mengikuti pembelajaran, pembelajaran menjadi menyenangkan, karena guru mengadakan permainan pembelajaran menjadi tidak 
membosankan dan manfaatnya pelajaran mudah dipahami Karenna guru memberikan contoh-contoh yang nyata melalui gambar". Menurut pendapat siswa 2 yang mewakili siswa pendiam,

"pembelajaran di dalam
kelas menjadi
menyenangkan dan tidak
membuat bosan karena ada
permainannya, manfaatnya
pelajaran yang sulit menjadi
mudah dipahami dann soal-
soal yang sulit menjadi
mudah karena semua sudah
dijelaskan oleh guru".

Angket persepsi siswa diberikan setelah kegiatan pembelajaran, masingmasing siswa mendapat satu angket dengan jumlah seluruh siswa kelas III yaitu 20 siswa dan tidak hadir 1 siswa. Dari hasil rekapan angket persepsi siswa terhadap keterampilan mengajar guru dengan menggunakan media visual gambar diperoleh kesimpulan yaitu siswa lebih mudah memahami pelajaran setelah guru menggunakan media pembelajaran karena semua penjelasan yang telah diberikan guru diperkuat dengan adanya contoh-contoh dari gambar.

Siswa lebih bersemangat lagi dalam mengikuti pembelajaran yang menggunakan media pembelajaran. Kegiatan pembelajaran menjadi lebih menyenangkan jika guru menggunakan media gambar dalam pembelajaran karena kegiatan pembelajaran tidak terlalu monoton dan tidak terlalu tegang. Materi pembelajaran menjadi mudah diterima oleh siswa dan siswa merasa nyaman dalam mengikuti pembelajaran di kelas. Siswa lebih rajin belajar karena media pembelajaran membuat siswa menyukai pelajaran.

Siswa merasa terbantu memahami materi dengan adanya media pembelajaran yang digunakan guru, selain itu dalam kegiatan pembelajaran di kelas, guru juga menguasai materi dan selalu memberikan contoh-contoh. Guru juga menghampiri siswa dan berkeliling kelas untuk membantu siswa yang merasa kesulitan dalam menangkap pelajaran bahkan perhatian guru tertuju pada seluruh siswa. Dari hasil rekapan angket diperoleh informasi bahwa guru tidak sering menggunakan media visual gambar pada saat kegiatan pembelajaran.

Keterampilan Mengajar Guru Dengan Menggunakan Media Visual Gambar

Peran guru sangatlah penting terhadap keberhasilan pembelajaran, keberhasilan pembelajaran tidak lepas dari kemampuan guru dalam mengajar. Dari hasil penelitian di kelas, guru menggunakan keterampilan 
mengajarnya mulai dari keterampilan bertanya, keterampilan memberi penguatan, keterampilan mengadakan variasi, keterampilan menjelaskan, keterampilan membuka dan menutup pelajaran, keterampilan membimbing diskusi kelompok kecil, keterampilan mengelola kelas, serta keterampilan mengajar kelompok kecil dan perorangan.

Guru menerapkan keterampilan mengajarnya dengan menggunakan media visual gambar agar dapat menyampaikan ilmu dan mentransfer ilmu dengan baik serta siswa dapat menerimanya dengan mudah. Hal ini sesuai dengan teori menurut Suparman (2010, hal.61) bahwa, " guru memiliki dua kemampuan yaitu memberikan ilmu dan mentransfer ilmu. Hanya saja proses pemberian dan transferisasi ilmu tidak akan berhasil dengan baik jika tidak memiliki metode/gaya mengajar yang jelas, terarah, memiliki tujuan dan sistematis. Oleh itu penerapan metode, model, strategi ataupun gaya mengajar sangat diperlukan agar proses penyampaian dan trasferisasi ilmu dapat berjalan secara maksimal dan sesuai dengan harapan".

Media pembelajaran merupakan alat bantu pada proses pembelajaran.
Fungsi media pembelajaran adalah untuk menyampaikan informasi yang belum tersampaikan secara lisan oleh guru. Hasil penelitian di kelas menunjukkan bahwa fungsi media pembelajaran sangat berpengaruh bagi siswa, dengan adanya media pembelajaran siswa lebih mudah memahami pelajaran dan lebih terbantu dengan adanya media. Kondisi ruang kelas menjadi menyenangkan dan siswa sangat antusias dalam mengikuti pembelajaran, minat belajar siswa menjadi tinggi. Hal ini sesuai dengan teori yang dikemukakan oleh Arsyad (2007, hal.15), "fungsi uama dari media pembelajaran adalah sebagai alat bantu mengajar guru yang berpengaruh terhadap iklim, kondisi, dan lingkungan belajar yang diciptakan oleh guru". Pemakaian media dapat membantu siswa dalam menerima materi pelajaran dan memudahkan siswa dalam menyerap ilmu pelajaran.

Kendala Guru Dalam Menerapkan Keterampilan Mengajar Menggunakan Media Visual

Kendala yang dialami guru dalam menerapkan keterampilan mengajarnya dengan menggunakan media visual gambar yaitu dalam penerapan keterampilan mengajar, guru tidak 
mengalami hambatan karena keterampilan mengajar tersebut ada dalam diri seorang guru dan inisiatifinisiatif itu muncul secara langsung pada saat kegiatan pembelajaran berlangsung. Hambatan yang dialami guru terletak pada pemanfaatan media gambar seperti kurangnya persiapan guru dalam menyiapkan media gambar, ukuran gambar sangat terbatas dan tidak cukup besar. Hal ini sesuai dengan teori yang dikemukakan oleh Sadiman, dkk (2009, hal.31), kelemahan media gambar yaitu gambar hanya menggunakan indera penglihatan, gambar sulit disesuaikan dengan pokok bahasan, dan tidak semua kejadian masa lalu dapat dibuat gambarnya.

\section{Persepsi Siswa $\quad$ Terhadap Keterampilan Mengajar Guru Dengan Media Visual}

Persepsi merupakan sebuah proses yang tidak hanya sekali jadi, melainkan melalui perlakuan yang berulang-ulang dan proses penggabungan, menginterpretasikan dan akhirnya memberikan penilaian. Hasilnya dari proses ini merupakan kesadaran individu terhadap keadaan sekelilingnya. Dari hasil penelitian di kelas, siswa mengikuti kegiatan pembelajaran di kelas yang menggunakan media visual gambar dalam proses kegiatan mengajarnya. Setelah kegiatan pembelajaran berlangsung siswa merasakan manfaat yang di dapat dari hasil pembelajaran di kelas dengan menggunakan media visual gambar. Hal ini sesuai teori menurut Laura (2012, hal.225), "persepsi merupakan proses otak dalam mengatur dan menginterpretasi informasi sensoris dan memberikan makna". Dengan demikian persepsi siswa merupakan suatu proses dimana siswa menginterpretasi dan memberikan respon atau tanggapan serta kesan terhadap pembelajaran yang telah dilakukan oleh guru.

Pada saat guru selesai menjelaskan, guru sering kali bertanya kepada siswa mengenai materi yang sudah dijelaskan sebelumnya. Guru memberikan pertanyan yang mengarah dan menuntun. Pada saat guru bertanya, siswa segera mencari jawaban yang ada di buku catatan dan langsung mengacungkan tangan untuk menjawab pertanyaan yang guru berikan. Siswa berlomba-lomba untuk menjawab pertanyaan yang guru berikan dengan mengangkat tangan. Hal ini sesuai teori menurut Soekanto (2012, hal.48), "respon diartikan sebagai perilaku yang perilaku yang sebelumnya sebagai tanggapan atau jawaban suatu

61 | Persepsi Siswa terhadap Keterampilan Mengajar Guru 
persoalan atau masalah tertentu". Respon siswa terhadap pembelajaran yang guru berikan yaitu siswa lebih bersemangat dalam mengikuti pembelajaran dan siswa terlihat antusias dalam menerima materi pelajaran yang guru berikan.

Pada saat menjelaskan, guru menunjukkan contoh-contoh yang nyata dari gambar-gambar yang sudah disiapkan sebelumnya. Guru menjelaskan materi pelajaran dengan runtut. Pada saat menjelaskan, siswa memperhatikan penjelasan guru, siswa tidak segan untuk bertanya kepada guru mengenai materi yang kurang dipahami. Siswa juga bertanya mengenai gambar yang kurang jelas atau tidak diketahui oleh siswa. Hal ini sesuai dengan teori menurut Slameto (2010, hal.105), perhatian adalah kegiatan yang dilakukan seseorang dalam hubungannya dengan pemilihan rangsangan yang datang dari lingkungannya. Perhatian merupakan kegiatan yang dilakukan oleh seseorang yang tertuju pada suatu objek atau sekumpulan objek. Perhatian siswa dalam pembelajaran yaitu kegiatan siswa yang dilakukan di dalam kelas yang tertuju pada pembelajaran yang sedang berlangsung dan tidak ada kegiatan lain yang dilakukan siswa.
Pada saat kegiatan pembelajaran berlangsung, di sela-sela pelajaran, guru mengadakan variasi permainan untuk menumbuhkan semangat belajar siswa dan gaya mengajar dengan gaya khas guru menggunakan suara yang lantang, tegas dan perhatian guru tertuju ke seluruh siswa. Guru mengadakan selingan permainan agar materi pelajaran mudah dipahami oleh siswa dan siswa tidak merasa bosan saat mengikuti kegiatan pembelajaran di kelas. Hal ini sesuai dengan teori Purwanto (2010, hal.44), pemahaman adalah tingkat kemampuan yang mengharapkan memahami arti atau konsep, situasi, serta faktor yang diketahuinya. Pemahaman juga merupakan kesanggupan untuk mendefinisikan, merumuskan kata yang sulit dengan perkataan sendiri. Pemahaman merupakan kemampuan dalam memaknai hal-hal yang terkandung dalam suatu teori maupun konsep-konsep yang dipelajari.

\section{Guru memberikan penguatan} untuk menguatkan pendapat siswa agar tidak keluar dari konteks pelajaran. Penguatan yang guru lakukan seperti pemberian pujian yang dinyatakan dengan ucapan kata atau kalimat dan penguatan dengan Bahasa tubuh, dimaksudkan agar siswa mau belajar 
lebih giat lagi. Siswa terlihat tekun mengerjakan soal-soal yang diberikan oleh guru, tidak putus asa dalam menghadapi kesalahan jika dalam jawabannya ada yang kurang benar. Hal ini sesuai dengan teori Hamzah (2011, hal.23), motivasi belajar adalah dorongan yang ada dalam diri seseorang baik internal maupun eksternal.

Pada saat mengelola kelas, guru mengkondisikan keadaan ruang kelas agar tetap tenang dan kondusif. Siswa juga tidak ada yang gaduh sendiri dan tetap fokus pada pelajaran dan penjelasan guru. Guru mendekati siswa yang kurang paham untuk diberi petunjuk dan penjelasan tambahan. Siswa terlihat selalu memperhatikan guru, berpartisipasi pada saat guru meminta menjawab secara lisan. Hal ini sesuai dengan teori Djaali (2008, hal. 121), minat adalah perasaan senang atau adanya ketertarikan pada sesuatu hal. Minat adalah kecenderungan untuk tetap memperhatikan dan mengingat sesuatu yang dipelajari secara terusmenerus. Ketika siswa ada minat dalam belajar maka siswa akan senantiasa aktif berpartisipasi dalam pembelajaran dan akan memberikan prestasi yang baik dalam pencapaian prestasi belajar.

\section{Kesimpulan}

1. Guru sudah menerapkan 8 keterampilan mengajarnya dengan menggunakan media visual gambar. Guru menerapkan keterampilan mengajarnya untuk menciptakan kondisi kelas yang kondusif agar siswa dapat belajar dengan nyaman dan senang sehingga pembelajaran dapat berjalan dengan lancar. Guru menggunakan media visual gambar karena media gambar mudah di dapat dan tidak memerlukan biaya yang banyak untuk proses pembuatannya.

2. Kendala yang dialami guru adalah guru kekurangan waktu dalam proses persiapan media, ukuran gambar yang tidak terlalu besar jika digunakan untuk jumlah siswa yang banyak sehingga menyebabkan guru harus mencetaknya cukup banyak agar dapat dibagikan kepada siswa. Gambar sulit dicari jika mempelajari sejarah masa lalu dan kejadian masa lalu. Gambar hanya menekankan persepsi indera mata saja sehingga jika tidak disertai penjelasan secara lisan oleh guru maka persepsi siswa terhadap gambar yang dimaksud akan berbeda.

3. Persepsi siswa mengenai pembelajaran yang sudah dilakukan oleh guru yaitu siswa merasa terbantu dengan adanya media pembelajaran,

$63 \mid$ Persepsi Siswa terhadap Keterampilan Mengajar Guru 


$\begin{array}{lcrll}\text { guru juga mengajar dengan } & \text { antusias sekali dalam mengikuti } \\ \text { keterampilannya sehingga dapat } & \text { pembelajaran di kelas dan terlihat } \\ \text { mempermudah siswa dalam } & \text { senang bahkan bersemangat dalam } \\ \text { menerima pelajaran. Siswa sangat } & \text { kegiatan belajar mengajar. }\end{array}$

\section{Daftar Pustaka}

Abidin, Y. 2009. Guru dan Pembelajaran Bermutu. Bandung: Rizqi Press

Arsyad, Azhar. 2007. Media Pembelajaran. Jakarta: Raja Grafindo Persada

B Sumantri. 2017. Pengaruh kemampuan, motivasi dan semangat kerja terhadap kinerja guru SMP Negeri di Balongpanggang, jurnal pendidikan. B Sumantri - e-Jurnal Mitra Pendidikan, 2017 - e-jurnalmitrapendidikan.com

Dimas Qondias, Erna Laurensia Anu, Irama Niftalia. 2016. Pengembangan Media Pembelajaran Tematik Berbasis Mind Maping Sd Kabupaten Ngada Flores. Tersedia pada: http://ejournal.undiksha.ac.id/inde x.php/JPI/article/view/8590/5844 Diputra Sujendra Komang. 2016. Pengembangan Multimedia Pembelajaran Tematik Integratif Untuk Siswa Kelas Iv Sekolah Dasar. Tersedia pada http://ejournal.undiksha.ac.id/inde x.php/JPI/article/view/8475/5839

Falahudin, I. (2014). Pemanfaatan Media dalam Pembelajaran. Jurnal Lingkar Widyaiswara, (4), 104-117.

Febrianto Agung. 2013. Pengaruh keterampilan mengelola kelas dan gaya mengajar guru terhadap keaktifan belajar siswa kelas XI materi pembelajaran pembangunan ekonomi sma negeri 2 slawi.Jurnal Penelitian Pendidikan. A Febrianto - Economic Education Analysis Journal, 2013 journal.unnes.ac.id

Ismawati, E., Santosa, G. B., \& Ghofir, A. (2016). Pengembangan Model Pembelajaran Sastra Indonesia Berbasis Pendidikan karakter di SMA/SMK. Metasastra, $\quad 9(3), \quad$ 185-200. $\quad$ https://doi.org/DOI: 10.26610/metasastra.2016.v9i2.185-200

Laura, A. King. 2012. Psikologi Umum. Jakarta: Salemba Humanika

Leow, F. T., \& Neo, M. (2014). Interactive multimedia learning: Innovating classroom education in a Malaysian university. Turkish Online Journal of Educational Technology, 13(2), 99-110. Retrieved from http://www.tojet.net/articles/v13i2/13211.pdf

Moleong, Lexy. J. 2010. Metodologi Penelitian Kualitatif. Bandung: PT. Rosdakarya

Pilemon Poly Maroa, Charles Kapile, Abdul Hamid. 2014. Penerapan Pembelajaran PKN Dengan Media Visual Untuk Meningkatkan Hasil Belajar Pada Siswa Kelas V SD Inpres 012 Bajawali Kecamatan Lariang Kabupaten Mamuju 
Utara. Jurnal Kreatif Tadulako. PP Maroa, C Kapile, A Hamid Jurnal Kreatif Tadulako Online, 2014 - jurnal.untad.ac.id

Purwanto, Ngalim. 2010. Prinsip-Prinsip dan Teknik Evaluasi Pengajaran. Bandung: PT. Remaja Rosdakarya

Rakhmat, Jalaludin. 2007. Persepsi Dalam Proses Belajar Mengajar. Jakarta: Rajawali Pers

Rahayu, S. (2015). Peningkatan Motivasi dan Keterampilan Menulis Puisi dengan Media Gambar pada Siswa Menengah Pertama. Kajian Linguistik Dan Sastra, $27(2)$, 126-133. https://doi.org/https://doi.org/10.23917/kls.v27i2.4481

Rohyatin, Dwi Yulianti, Suyono. 2017. Peningkatan Hasil Belajar IPA Dengan Menggunakan Media Visual Gambar Pada Siswa Kelas VI SD Negeri Bumi Agung Kalianda. Jurnal Teknologi Informasi. R Rohyatin, D Yulianti... Jurnal Teknologi Informasi ..., 2017 - jurnal.fkip.unila.ac.id

Usman, Moh. Uzer. 2010. Menjadi Guru Profesional. Bandung: PT Remaja Rosdakarya

Walgito, Bimo. 2010. Pengantar Psikologi Umum. Yogyakarta: C.V Andi Offset 